\title{
Gynaecological Endocrinology
}




\title{
Gynaecological Endocrinology
}

A Guide to Understanding and Management

\author{
Maureen Dalton \\ Consultant in Obstetrics and Gynaecology \\ Sunderland Area Health Authority \\ Tyne and Wear, UK
}

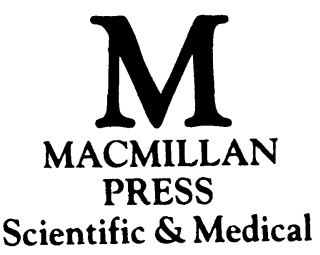


(C) Maureen Dalton, 1989

Illustrations (C) St James's University Hospital, Leeds 1989

All rights reserved. No reproduction, copy or transmission of this publication may be made without written permission.

No paragraph of this publication may be reproduced, copied or transmitted save with written permission or in accordance with the provisions of the Copyright Act 1956 (as amended), or under the terms of any licence permitting limited copying issued by the Copyright Licensing Agency, 33-4 Alfred Place, London WC1E 7DP.

Any person who does any unauthorised act in relation to this publication may be liable to criminal prosecution and civil claims for damages.

First published 1989

Published by

THE MACMILLAN PRESS LTD

Houndmills, Basingstoke, Hampshire RG21 2XS

and London

Companies and representatives

throughout the world

Typeset by Gecko Limited, Bicester, Oxon

ISBN 978-0-333-47492-1

ISBN 978-1-349-20209-6 (eBook)

DOI 10.1007/978-1-349-20209-6 


\section{Contents}

Preface vi vili

Introduction viii

1 The Hypothalamus 1

2 The Pituitary Gland 5

3 The Gonads 9

4 The Thyroid and Adrenal Glands 12

5 Endorphins and Prostaglandins 19

6 Fat 21

7 Mechanisms of Hormone Action 23

8 Steroid Biochemistry 27

9 Investigations 32

10 The Normal Menstrual Cycle 37

11 Puberty 43

12 The Breast 53

13 Amenorrhoea 57

14 Excessive Menstruation 67

15 Dysmenorrhoea 74

16 Hirsutism 77

17 The Premenstrual Syndrome 84

18 Infertility 91

19 Fertility Control 101

20 Endocrinology of Pregnancy 109

21 The Menopause 114

22 Drugs Used in Gynaecological Endocrinology 120

Bibliography $\quad 130$

Index 


\section{Preface}

This book has been written to help junior doctors, many of whom have confided in me that they dreaded the gynaecology clinic because they never knew what they could do for the follow-up patient with endocrinological problems, leaving them with a sense of unease about the management of such patients.

Inevitably there will be many who will criticize the book, claiming that too much has been left out or too much put in, and that I have not mentioned their favourite drug or theory. But this guide was not written for those with extensive knowledge of the subject, but for SHOs and others who need the help this book aims to provide.

Theories change and knowledge will eventually change some of the views now held in this rapidly developing field, but the reader will inevitably develop his own reference works as his knowledge and experience grow. Suitable starting works are included in the Bibliography.

There is some deliberate duplication, as it is intended that the book can be 'dipped into' as required and will not necessarily be read from cover to cover. However it is my hope that it will provide for the SHOs and other doctors a useful guide to the understanding and management of the gynaecological patient with endocrinological problems.

I am grateful to Mr Hamish Macdonald, John Barratt, Kate Guthrie and Kaly Bhabra for reading and criticizing the manuscript. Without their hard work this would definitely have been a less complete book. My sincere gratitude also to St James's Hospital Leeds Medical Illustration Department and in particular to Mr Bryan Emmison for his hard work in producing the wonderful illustrations. Thanks also go to $\mathrm{Mr}$ David Grist and $\mathrm{Mr}$ Richard Powell at The Macmillan Press for their patience, time and guidance, and to David, Sarah and Jennie Holton for their help with the index.

I must also express my special thanks to my parents for their untiring help and encouragement and, finally, but most importantly, to my sister Wendy, who had the unenviable task of 
translating my indecipherable scribbling into the semblance of a manuscript.

To all of you - thank you.

Leeds, 1989

M.D. 


\section{Introduction}

This book is not designed to be read from cover to cover. It is meant to be a guide for those who are uncertain about how to manage the diseases described here. Gynaecological endocrinology is a subject where rapid changes are made. This leaves many worried that the subject, which they never really understood as a student, has changed too rapidly. The first section provides a refresher of the physiology, especially aspects such as steroid biochemistry and hormone action which tend to be forgotten by the stage the SHO needs to understand them. The clinical chapters employ tables, figures and flow diagrams as it is hoped that they will help the reader to use the book as a practical guide. For this reason the same picture of a woman has been used repeatedly in figures with overdrawing of the salient features. Those with a pictorial memory will start to remember the aspects to look for in, for example, the examination of hirsutism or menorrhagia from these pictures.

The chapters in the clinical section are arranged in an approximate order of chronological age, from menarche to menopause. They cover the common problems. The starting point in each case is the presenting complaint, e.g. menorrhagia or dysmenorrhoea rather than the common diseases. Thus endometriosis or hypothyroidism will be discussed in more than one chapter. However patients do not present with a tag stating the disease, rather with symptoms. The causes, relevant points of the history and examination, investigations and possible methods of treatment are then covered.

It is hoped that using the diagram of the same woman each time will help to reinforce that the patient should be seen as a whole and that the clues to the answer to the problem do not always lie within the pelvis. 